\title{
The Development of Thematic Lesson Plan Based on Character to Improve Social Behavior of Fifth Grade Students in Elementary School
}

\author{
Nurul Luthfiyah $^{*}$ Suwarjo $^{2} \quad$ Pargito $^{3} \quad$ Darsono $^{4}$ \\ Faculty of Teacher Training and Education, University of Lampung \\ St. Soemantri Brojonegoro No.1 Gedung meneng Bandar Lampung 35145
}

\begin{abstract}
This study aims to develop thematic lesson plan based on character, which uses the Problem Based Learning and Backward Design models that are feasible and effective to foster the social behavior of fifth grade students in elementary schools. The type of research used in this study refers to the theory of Borg \& Gall. The population in this study were educators grade V North Metro Elementary School. The sample was determined using a purposive sampling technique of 8 educators from grade $\mathrm{V}$ public elementary schools 1 North Metro, public elementary school 2 North Metro, public elementary school 3 North Metro, public elementary school 4 North Metro, and state elementary school 5 North Metro. Data is collected through questionnaire sheets, observations and test results. Theoretical Feasibility of the Lesson Plan is based on the assessment of several experts who obtained an average score of 83,07 in the "very good" category. The empirical feasibility of the RPP is based on the analysis of items on the validity, reliability, difference power, and difficulty level test. Hypothesis testing shows that social behavior achieved by students who use Lesson Plan based on character gets more effective observation results than those who do not use Lesson Plan based on character.
\end{abstract}

Keywords: Lesson Plan, backward design, problem based learning, character, social behavior.

DOI: $10.7176 / \mathrm{JEP} / 10-23-09$

Publication date: August $31^{\text {st }} 2019$

\section{INTRODUCTION}

Character is a very essential thing in nation and state, loss of character will cause the loss of future generations. According to Lickona (2015: 6) character is a good and right action taken to someone to another person. According to him a good character consists of knowing good things, wanting good things, and doing good things, habits in ways of thinking, habits in the heart and habits in action. Whereas according to Philips (in Masnur 2011: 70), character is a collection of values that lead to a system, which underlies a thought, attitude, and behavior displayed. Good character can be created through effective learning, one of the way is by applying character education to students. In Elementary School, character education must be applied, through learning done at school. Fauziyah (2014: 149-163) reveals that the Indonesian nation is currently experiencing a breakdown in character, good ethics and morals, and a crisis of social behavior, it is fitting that education is now used as a place of learning about values, morals, ethics, character and morality whose role is very large even though the role of the environment and family is much greater, but in reality learning of values, morals, ethics, character and morals in school has not been implemented optimally. The success of a teacher in teaching is expected, in order to achieve the desired goals.

Before the teacher teaches students, teacher is expected to be able to prepare the material that will be taught or presented to students, prepare props / labs to be used, prepare questions and directions to provoke students to actively learn, learn the condition of students, understand weaknesses and strengths of students, and learn knowledge the beginning of students, these things will break down the implementation in the learning device. Learning devices become the teacher's grip in carrying out learning both in class, laboratory, and outside the classroom. According to Bohlin. TO. (2018: 370-397) A good character for students is that students can make good decisions responsibly and become good citizens.

Character education is basically aimed at forming a strong, competitive, noble, moral, tolerant, collaborative, patriotic, dynamic, science and technology which is all inspired by faith and piety to the Almighty God. Each teacher teaches not only transmits and requires students to master the field of science, but the teacher must also teach students to be human beings who have good character or have noble character. Teachers must be able to carry out their teaching tasks well and professionally. Before teaching the students, the teacher must be able to prepare all the media, and the learning tools that needed.

One of the way to accomplish that goal is the Lesson Plan. According to Jensen (in Jantarach, 2018: 403-413) lesson plan or learning plans are very useful tools that serve as combination guides, resources, and historical documents that reflect the philosophy of teaching, population of students, textbooks, and most importantly, teacher goals for students. A lesson plan is very important for beginner teachers and is comfortable in its use for experienced teachers. Whereas according to Adlin (2014: 1-10) Lesson Plan is a systematic and sequential description of the syllabus which is set forth in the learning objectives, teaching materials, methods, learning steps, 
learning resources, assessment of learning outcomes, and time allocation to achieve a Competency Basic or some indicators in the syllabus. The development of the Lesson Planstill refers to Regulation of the Minister of National Education No. 22 of 2016 and collaborated with the Backward Design model.

According to Wiggins and McTighe (in Jack 2013: 5-33) backward design is a method of designing an educational curriculum by setting goals before choosing instructional methods and forms of assessment. Backward Student-centered curriculum design is carried out by step identifying objectives, conducting assessment before the learning process takes place (formative), planning learning and learning experiences, and finally the final assessment of learning (summative) is final. Good integration in the form of character values is included in the Learning Implementation Plan, development of character values is taken by examining Core Competencies and Basic Competencies, determining whether the content of character values is implied or explicit in Core Competence or Basic Competence, developing the learning process active students that enable students to have the opportunity to internalize values and show them in appropriate behavior and provide assistance to students who have difficulty internalizing values or show them in everyday social attitudes.

Uno (2012: 2) states the Lesson Plan is a design that is made satisfactorily to make the activity run well, accompanied by various anticipatory steps to minimize the gap that occurs so that the activity reaches its intended purpose. The purpose of learning is not only to develop cognitive abilities of students, but also very important to develop psychomotor and affective abilities. Amonashvili (in Zakirovaa 2016: 1835) records positive social behavior of students can through experience and reasonable attitudes towards reality. One of the positive social behavior is in the affective development of students is the social behavior of students can be accustomed to using the initial steps of the Lesson Plan that is made using a variety of models and interesting learning methods will create learning experiences in students, so that learning is able to achieve the desired goals.

Meanwhile, according to Meydan (in Yilmaz 2017: 289-298) the application to students about social behavior is very useful, social learning in elementary schools helps students to have a better understanding of the surrounding environment, strengthen love for the country, develop the ability to understand problems in lessons in class, children also find opportunities to more understand the surrounding environment and understand every role in developing social personalities.

\section{RESEARCH METHODS}

The research and development used in this study refers to the theory of Borg \& Gall (1983: 781) on Research \& Development which has research objectives namely research procedures with the aim of developing and validating educational products developed, this research and development consists of 10 steps namely, gathering information and initial research, making plans, developing initial product models, conducting initial trials in the field, conducting major product revisions based on the results of the initial trial, conducting the main field trials, conducting revisions to operational products based on the results of the main trials, conducting tests try operations in the field, make revisions to final products, and disseminate and implement products. In this study the steps of research and development are only up to stage seven, namely revision of operational products, because of the limitations of researchers, both in terms of time and cost. The population in this study were educators grade $\mathrm{V}$ North Metro Elementary School. The sample was determined using a purposive sampling technique of 8 educators from 5 elementary schools.

The development of thematic lesson plan based on character uses a data collection tool in the form of a questionnaire, for material validation, media, language and practitioners. The material aspects of the RPP include conformity with the backward design model, and character loads. The media aspect of RPP fulfills didactic, construction, and technical requirements. Language aspects contain the use and selection of the right words or sentences. Practical aspects are in the form of instructions from the steps to use character-based thematic lesson plans. The percentage value of social behavior was obtained from observations several times.

development of thematic lesson plans based on character use a data collection tool in the form of a questionnaire, for validation of material, media, language and practitioners. The material aspects of the RPP include compatibility with the backward design model, and character content. The media aspects of the RPP fulfill didactic, construction and technical requirements. Aspects of language include the use and selection of words or sentences that are appropriate. The practitioner aspect is in the form of instructions from the steps for using character-based thematic lesson plans. The percentage value of social behavior is obtained from observations of several meetings. Learning outcomes are obtained from the results of the pretest and posttest learning using character-based thematic lesson plans, using valid and reliable test instruments, and taking into account the different levels of difficulty and questioning power. Essay instrument given a score varies depending on the level of difficulty of the questions.

\section{RESEARCH RESULTS AND DISCUSSION}

\subsection{Research result}

The results of the research and development of thematic lesson plans based on character to improve students' social 
behavior in product development with the development procedure referring to the development model of Borg \& Gall (1983: 781) obtained the following results.

3.1.1 Collection of Initial Information

The initial information collection was carried out through preliminary research by observing the learning process and collecting learning outcome documents in the fifth grade of elementary school in North Metro sub-district. The results of the preliminary research are used as a consideration and the basis for the development of lesson plans. This step needs to be done because this development research tests a product in the form of thematic lesson plans based character whose development must be based on empirical data about the profile and subject under study based on observations of student behavior and analysis of student learning outcomes and educator needs analysis at 6- September 7, 2018 in the fifth grade of elementary school in North Metro sub-district.

3.1.2 Planning

The planning of the development of thematic lesson plans based on character is, the initial preparation of thematic lesson plans based on character, presentation of Indicators in accordance with KD, learning objectives in accordance with indicators with character content, preparation of summative assessment in accordance with the objectives to be achieved, learning steps with models and methods memorable, planning evaluation tools, and preparing assessment instruments.

\subsubsection{Development of lesson plans}

The first stage carried out by the researcher was analyzing the curriculum and analyzing the contents of KI and $\mathrm{KD}$, then drafting the lesson plans in accordance with the backward design model, namely formulating indicators in accordance with the $\mathrm{KD}$, followed by formulating learning objectives in accordance with the terms associated with character and social behavior, then do formative assessment to see and know students' understanding of learning material by assessing the character of students directly, followed by implementing the process of learning activities according to the needs of students viewed from the results of previous formative assessments. The results of this product design are in the form of thematic lesson plans based on character for theme 9 of sub-theme 3 which are equipped with questions and grids of assessment questions and observation instruments towards students' social behavior.

\subsubsection{Product Testing}

The initial product trial was conducted by 3 validation experts, namely material experts, media experts, and linguists. Aside from the validator lecturers, an expert practitioner was also assessed by the results of each of the 3 schools, namely; 79.5 SDN 1 Metro Utara, 80.6 for SDN 2 Metro Utara, and 80.6 SDN 3 Metro Utara. In addition to the validation of the practitioner or teacher, the initial product trial also tests the validity, reliability, different power tests and the level of difficulty to see the validity of the instrument based on character-based lesson plans. 3.1.5 Initial Product Revision

Through testing the initial product to get results and input suggestions from the validator then the next revision is carried out, and the results will get the results used for the improvement of the developed lesson plans.

\subsubsection{Main Field Trial}

Trials of Lesson Planwere conducted at Public Elementary School 1 in North Metro as an experimental class that using Lesson Plan based on Character and in Public Elementary School 2in North Metroas a control class that did not receive treatment or did not use esson Plan based on Character. Field trials were carried out on April 8-20 in fifth grade. The subjects of the study were conducted by teachers in 30 students in the experimental class and 21 in the control class. Field trials were carried out for 6 meetings at each school. In this stage, it is analyzed to see the quality of the development of a feasible and effective Lesson Plan. Observation of social behavior by using the assessment of students' observations during the learning activities taking place that using thematic Lesson Plan. The results of observations of social behavior from 30 experimental group students included 26 students $(85 \%$ $100 \%)$ in very good categories, 1 student (76-85\%) in good category, 3 students $(60 \%-75 \%)$ with sufficient categories, and there are no students with less categories. The data shows that the social behavior of students is good during the learning process using the Thematic Lesson Plan. For observations of social behavior in the control class there was no difference because they did not get treatment.

\subsubsection{Final Product Revisions}

Based on a large group trial, the results of social behavior and students learning outcomes were increased. The learning outcomes of students, the validation of linguists, material, media experts and practitioners are the references in making conclusions that the Thematic Lesson Plan based on Character is not revised and is feasible to be implemented.

\subsection{Discussion}

3.2.1 The Development of a Thematic Lesson Plan based on Character

The Development of a Thematic Lesson Plan based on Characteris focused on fifth grade with theme 9 of the Objects Around Us with the sub-theme 3 of Humans and Objects in the Environment. The Development of a Thematic Lesson Plan based on Character adopts R \& D steps by Borg \& Gall (1983: 784) using seven of ten 
steps. The first stage is the initial research and information gathering, after the researcher knows the problems that occur the researcher conducts a plan to develop Thematic Lesson Plan based on Character that will be used by the teacher as a tool to improve students' social behavior seen from the observations of students. Next the researcher compiles the initial product development of Lesson Plan, in this step the researcher sets out the pattern of developing the content and design of the Thematic Lesson Plan based on Characterin accordance with the backward steps of the design. Zurqoni (2018: 370-397) the importance of good character for students is to give them the skills needed in order to overcome various challenges and problems in their social environment. By having good character, they are expected to be able to apply and improve moral values and abilities and realize moral values in their daily lives.

The next stage is the initial trial. This stage the researcher conducted a validation test and a small group trial. The validation test is carried out by 4 validators, that are linguists, material experts, media experts, and fifth grade practitioners with the aim of validating the products developed whether they are in accordance with the development requirements so that they are feasible to be tested. then the average validation results for the material expert aspect obtained a value of 93.76 (very good), the results of the validation aspects of the media design expert obtained a value of 93.76 (very good), and the validation of linguists gained 90 (very good), and the response practitioner or user gets 87.5 (very good). These results indicate that the learning tools of the Lesson Plan have very good validity. Thus, learning devices in the Lesson Plan are declared feasible to be tested in learning after revisions are made. The researcher made a product revision for suggestions and comments from the validators. After the product is declared valid and feasible to be tested. Furthermore, validation was also carried out by 8 practitioners from 5 elementary schools. Then the researcher made a revision to improve the product.

Thus, the lesson plan was declared worthy to be tested in learning after it was revised. Researchers make product revisions to the suggestions and comments of the validators. After the product is declared valid and worth testing, the next step is the small group trial phase. The results obtained based on observations get increased, and the results obtained based on the pretest and posttest there is an increase in student learning outcomes. Then the researchers made a revision to improve the product. Next to the field trial stage, the character-based thematic lesson plan products are tested in the learning process. This field trial phase is used to determine the feasibility of character-based thematic lesson plans in improving social behavior as seen from the observations and learning outcomes of students in the pretest and posttest. Therefore, this character-based thematic lesson plan product is not revised and is feasible to be implemented.

This study refers to the results of Layin \& Jailani's research (2014: 149-163) which shows that the effectiveness of the RPP must go through the process of student learning in groups, discussing, and developing skills based on understanding that can make students actively build and find their own knowledge so that the understanding process concepts are more easily internalized into real world contexts. Referring to Flournoy's research (in Asyhari, et.al., 2014: 62-75) his research revealed that facilitating students with a comfortable environment, will develop students' character and be able to improve their learning achievement. This is because a comfortable environment will change the behavior patterns of students in learning positively. This comfortable environment can be created at home or at school.

\subsubsection{The strengths of the Thematic Lesson Plan based on Character Thematic}

Lesson Plan based on Character is a product of development that has the following advantages.

a. Lesson Plan that developed is a Thematic LeLesson Plan in accordance with the Curriculum2013.

b. Lesson Plan are presented by writing clear, straightforward language, and containing instructions to describe activities that are easy to understand.

c. The Lesson Plan contains characters from the learning objectives, to the end of the description of activities that can be used to familiarize students with good behavior according to the expected character.

d. The Lesson Plan contains questions that have been validated theoretically and empirically and there are descriptions of learning materials that are in accordance with the theme being taught.

\section{CONCLUSION}

Based on the results of the research and discussion it can be concluded that the Lesson Plan developed is theoretically and empirically feasible to foster the social behavior of fifth grade elementary school students. This is evidenced through the assessment of experts, that are material experts, media experts, language experts and practitioners or users who state that the Lesson Plan developed in the category is very good. In addition, Lesson Plan based on Characteris also equipped with questions that meet the appropriate criteria in the test of validity, reliability, level of difficulty, and power difference. Lesson Plan based on Characteris carried out in the stages of small group trials, and large group trials. Furthermore, testing hypotheses that shows that the use of the Lesson Plan based on Character is effective in fostering the social behavior of fifth grade elementary school students. The conclusion is based on empirical data which shows that there are improvement of students' social behavior at each meeting and with the results of tests that have been conducted by validation experts. 


\section{REFERENCES}

Asyhari, Ardian. dkk. 2014.Pengembangan Perangkat Pembelajaran Fisika Sma Berbasis Inkuiri Terbimbing Terintegrasi Pendidikan Karakter. Jurnal Inkuiri. Vol 3 (1), hal. 62-75.

Borg, R Walter \& Gall, D Meredith. 1983. Educational Research An Introduction.Fourth Edition. Longman. New York.

Fauziyah Layin, \& Jaelani. 2014. Pengembangan Perangkat Pembelajaran Matematika Yang Menunjang Pendidikan Karakter Siswa Kelas IV SD. Jurnal Prima Education. Indonesia.Vol.2 (2). hal.149-163

Jack C. Richards. 2013. Curriculum Approaches in Language Teaching: Forward, Central, and Backward Design. University of Sydney, Australia; RELC, Singapore, vol. 44 (1), hal. 5-33.

Kaf, O., \& Uygungul Yilmaz, O. 2017. Effects of creative drama method on students' attitude towards social studies, academic achievement and retention in Turkey. European Journal of Educational Research, vol. 6 (3), hal 289-298.

Lee A.Becker, 2000. Effect Size Measures For Two Idependent Groups, (Journal: Effect Size Becker).

Lickona, Thomas. 2015. Character Matters; Persoalan Karakter, Bagaimana Membantu Anak Mengembangkan Penilaian Yang Baik, Integritas dan Kebajikan Penting Lainnya.Bumi Aksara. Jakarta.

Masnur, Muslich. 2011. Pendidikan Karakter Menjawab Tantangan Krisis Multidimensional. Bumi Aksara. Jakarta.

Rahmawati, Rajina. Zakirova et.al. 2016. Content and Methodological Formation Model of a Younger Pupil Value-Oriented Attitude to Reality Based on Historical and Social Science Knowledge.International Journal Of Environmental \& Science Education. Russia.Vol. 11 (8), hal.1833-1848.

Ryan, K. \& Bohlin, K.E. 2018. Building character in schools: Practical ways to bring moral. Journal of Social Studies Education Research. San Fransisco. Vol. 9 (3), hal. 370-397.

Uno, Hamzah B. 2012. Perencanaan Pembelajaran. Bumi Aksara. Jakarta.

Vachira Jantarach, 2018. EFL Student Teachers' Lesson Planning Processes: A Grounded Theory Study. Arab World English Journal (AWEJ), vol. 9(3). hal. 403-413.

Zurqoni, et al. 2018. Strategy and Implementation of Character Education in Senior High Schools and Vocational High Schools. Journal of Social Studies Education Research. Indonesia. Vol. 9 (3), hal. 370-397. 